\title{
HUBUNGAN GAYA HIDUP DAN KEBIASAAN MAKAN DENGAN KADAR HAEMOGLOBIN (Hb) PADA ANAK JALANAN DI KOTA MEDAN
}

\author{
Ginta Siahaan \\ Dosen Jurusan Gizi Poltekkes Kemenkes Medan
}

\begin{abstract}
According to Law No. 23 The year 2002 about child protection, the rights of the child is part of a compulsory human rights guaranteed, protected and fulfilled by parents, society, government and state. while in Article 4 paragraph 1 mentioned that the children who have no parents are entitled to by the state or the nursery or the body. This research aims to know the relationship between eating habits and Lifestyle with the level of Haemoglobin $(\mathrm{Hb})$ on the Street Children in the City of Medan. This research done in some places where ordinary street children abstain as Simpang Red light Titi Kuning, Aksara, Juanda, Pringgan, Simpang Petisah and Terminal Amplas, and Pinang baris in the city of Medan. Data collection is done for 1 months starting from April 20 s/d 20 May 2013, where the location of this research are expected to represent the community of street children in the city of Medan. The type of this research is cohort studies with cross sectional design (cut bars). The population in this research is the whole street children Simpang Red light Titi Kuning, Aksara, Juanda, Pringgan, Simpang Petisah and Terminal Amplas, and Pinang baris in the city of Medan. estimated 300 people, now samples on the research is part of the population of street children based on the criteria of inclusion where one of the criteria is the street children aged 14 - 24 years. From these criteria get samples as much as 72 people. This research has been approved by the code of conduct research FK USU. Based on the results of research can be concluded that the lifestyle of street children is to have the categories less of 36 people (50\%), and eating habits of street children are the most is have less category of 28 people (38.9\%) while for the level of haemoglobin $(\mathrm{Hb})$ street children are the most is have low category of 42 people (58\%), to see the relationship between the statistical tests with Test Chi-Square, where there is a significant relationship $(p=0.000<0.05)$ between lifestyle with the level of haemoglobin $(\mathrm{Hb})$, whereas there is no significant relationship $(p=0.096>0.05)$ between eating habits with the level of haemoglobin $(\mathrm{Hb})$. The researcher recommends that for an observer of street children should perform routine counseling every month so that the street children can be exposed to about the lifestyle that hygiene, kiebiasaan eat good and orderly pentinhnya eat for street children.
\end{abstract}

Keywords : Lifestyle, eating habits, haemoglobin level

\section{PENDAHULUAN}

Krisis ekonomi yang melanda indonesia tahun 1997 menyebabkan banyak pengangguran. Kondisi ini menyebabkan banyak para remaja untuk memenuhi kebutuhan hidup menjadi pengamen. Pekerjaan pengamen bukan hanya sekedar tetapi menjadi mata pencaharian terutama pada anak yang tidak mempunyai tempat tinggal yang tetap. Pemetaan sosial terhadap 12 kota besar di Indonesia yang dilakukan oleh PKPM Universitas Atmajaya pada tahun 1999 menunjukkan bahwa jumlah anak jalanan di berbagai kota besar amatlah tinggi. Pemetaan menujukkan ada sekitar 39.861 anak jalanan di berbagai kota besar sekitar 10.373 berada di Jakarta, 2.832 di Bandung dan 2.835 di Surabaya sedangkan untuk kota Medan mencapai 4.200 orang (Suyanto, 2010).

Menurut Undang-undang no 23 tahun 2002 tentang perlindungan anak, hak anak adalah bagian dari hak asasi manusia yang wajib dijamin, dilindungi dan dipenuhi oleh orangtua, masyarakat, pemerintah dan negara. Sedangkan dalam pasal 4 ayat 1 disebut bahwa anak yang tidak mempunyai orangtua berhak memperoleh asuhan oleh negara atau orang atau badan. Kemudian, pasal 5 ayat 1 menyebutkan bahwa yang tidak mampu berhak memperoleh bantuan agar dalam lingkungan keluarganya dapat tumbuh dan berkembangnya secara wajar (Handayani, 2009).

Anak jalanan adalah anak-anak yang tersisih, marginal (kumuh), dan teralienasi (terasing, terisolasi) dari perlakuan kasih sayang karena kebanyakan dalam usia dini sudah harus berhadapan dengan lingkungan kota yang keras bahkan tidak bersahabat. Anak jalanan harus bertahan hidup dengan cara sosial yang kurang atau bahkan tidak diterima masyarakat umum (Suyanto, 2010).

Sesungguhnya banyak faktor yang menyebabkan anak-anak berada dalam kehidupan jalanan, seperti kesulitan keuangan atau tekanan kemiskinan, ketidakharmonisan keluarga, pengaruh teman atau kerabat, pilihan hidup seseorang dan masalah khusus menyangkut hubungan dengan orangtua (Siregar, 2004). 
Anak jalanan cenderung mempunyai gaya hidup bebas, higyene sanitasi rendah karena jarang mandi, hidup di ruko-ruko, aktifitas sehari mereka mendekati 24 jam. Dengan keadaan-keadaan lingkungan yang tidak saniter serta higyene sanitasi mereka yang buruk, pola-pola kesehatan yang salah serta kebersihan makanan tidak terjaga sehingga bisa terkena infeksi penyakit dan kecacingan. Prinsip anak jalanan makan untuk hidup, melakukan kegiatan yang bermacam-macam. Anak jalanan cenderung hidup dengan pergaulan bebas, melakukan free sex sehingga tidak jarang terjadi kehamilan yang tidak diinginkan. Resiko yang timbul akibat kehamilan yang tidak diinginkan adalah melakukan aborsi atau melahirkan yang terkadang menyebabkan perdarahan hebat akibat tidak ditolong oleh tenaga kesehatan yang profesional, pengeluaran darah yang demikian banyak dapat menyebabkan anemia (Kusmiran , 2011).

Keadaan ini diperparah asupan makanan yang dikonsumsi sehari-hari rendah zat gizi terutama Fe, protein beserta B12. Hal lain yang memperburuk anemia yaitu proses menstruasi serta di pengaruhi asupan makanan yang kurang baik. Dengan bermodalkan hidup dijalanan kebiasaan makan mereka tidak teratur, sehingga merupakan pemicu utama munculnya perubahan kebiasaan makan yang tidak sehat. Karena tingkat daya beli rendah mengakibatkan makan yang dipilih tidak bergizi dan lebih sering mengkonsumsi makanan junk food karena harganya relatif murah. Sehingga jumlah makanan berkualitas dan zat gizi yang dikonsumsi juga rendah (Hidayah, 2011).

Selain makan tidak teratur, mereka juga suka mengkonsumsi alkohol, dan narkoba supaya bisa lebih berani untuk menjalani hidup serta untuk melupakan penderitaan mereka. Tanpa mereka sadari mengkonsumsi alkohol dapat menghambat penyerapan $\mathrm{Fe}$, jika tubuh kekurangan $\mathrm{Fe}$ dapat berpengaruh terhadap kadar hemoglobin $(\mathrm{Hb})$. Sedangkan jika mengkonsumsi narkoba nafsu makan mereka menjadi menurun (Widiawati, 2007)

Hemoglobin $(\mathrm{Hb})$ adalah parameter yang digunakan secara luas untuk menetapkan prevalensi anemia. Hemoglobin $(\mathrm{Hb})$ merupakan senyawa pembawa oksigen dari paru-paru ke seluruh jaringan tubuh dan membawa kembali karbondioksida dari seluruh sel ke paru-paru untuk dikeluarkan dari tubuh. Hemoglobin dapat diukur secara kimia dan jumlah $\mathrm{Hb} / 100 \mathrm{ml}$ darah dapat digunakan sebagai indeks kapasitas pembawa oksigen pada darah. Kandungan hemoglobin ( $\mathrm{Hb})$ yang rendah demikian mengindikasian anemi (Supriasa, 2002).

Anemia gizi adalah keadaan dimana kadar haemoglobin $(\mathrm{Hb})$ lebih rendah dari nilai normal karena kekurangan zat besi. Di Indonesia prevalensi anemia pada remaja putri tahun 2006, yaitu 28\%.Data Survei Kesehatan Rumah Tangga (SKRT) tahun 2004. Anemia pada remaja putri masih menjadi masalah kesehatan masyarakat bila prevalensinya lebih dari $15 \%$ (SKRT, 2001). Dimana berdasarkan hasil penelitian pada remaja putri di Bogor 57,1\%; di Bandung $41 \%$ dan di Tangerang 41,7\% menunjukkan remaja putri menderita anemia (Handayani, 2009).

Berdasarkan masalah dan data yang ditemukan diatas maka penulis tertarik untuk meneliti "Hubungan Gaya
Hidup dan Kebiasaan Makan Dengan Kadar Hemoglobin (Hb) pada Anak Jalanan”.

\section{METODE PENELITIAN}

Penelitian ini dilaksanakan di beberapa tempat dimana anak jalanan biasa beraktifitas seperti di Simpang Lampu Merah Titi Kuning, Aksara, Juanda, Pringgan, Simpang Petisah serta Terminal Amplas, dan Pinang Baris di kota Medan. Pengumpulan data dilakukan selama 1 bulan mulai dari tanggal 20 April s/d 20 Mei tahun 2013. Dimana lokasi penelitian sudah diharapkan mewakili komunitas anak jalanan yang ada di kota Medan.

Penelitian ini bersifat Observasional dengan desain Cross Sectional (potong lintang) dimana variabel bebas dan variabel terikat dilihat pada waktu yang bersamaan untuk mengetahui Hubungan Gaya Hidup dan Kebiasaan Makan Dengan Kadar Hemoglobin ( $\mathrm{Hb}$ ) Pada Anak Jalanan Di kota Medan (Siagian, 2010). Penelitian ini disetujui oleh kode etik penelitian FK USU.

Populasi dalam penelitian ini adalah seluruh anak jalanan di Simpang Lampu Merah Titi Kuning, Aksara, Juanda, Pringgan, Simpang Petisah serta Terminal Amplas, dan Pinang Baris di kota Medan yang berjumlah 300 orang.

Sampel penelitian ini adalah bagian dari populasi, dimana dalam penentuan sampel terlebih dahulu di lakukan screening lalu penentuan sampel dilakukan dengan kriteria inklusi :

a. Berumur 14-24 tahun (Handayani, 2009)

b. Bersedia menjadi sample dan bekerja sama

c. Tidak dalam keadaan sakit (flu, demam, batuk)

d. Pada sampel wanita tidak mengalami menstruasi pada saat penelitian

e. Dapat berkomunikasi dengan baik

f. Kehadiran 6 kali dalam seminggu di lokasi tempat kerja

Dari kriteria inklusi yang telah ditetapkan maka ditemukan sampel anak jalanan sebanyak 72 orang.

Jenis data yang dikumpulkan yaitu data primer yang dibantu oleh 6 orang enumerator. Data primer, meliputi Data Identitas, Tingkat Kebiasaan Makan, Tingkat Gaya Hidup, Pengukuran Kadar Hemoglobin.

Cara pengumpulan data dilakukan dengan cara mendatangi tempat komunitas anak jalanan tersebut, melakukan wawancara dengan menggunakan kuesioner yang telah berisi sejumlah pertanyaan dan dibantu oleh enumerator.

- Meliputi data identitas sampel (nama, jenis kelamin, umur, alamat) yang diperoleh dengan wawancara langsung dengan menggunakan Form Identitas anak jalanan.

- Tingkat kebiasaan makan diperoleh dengan menggunakan kuesioner (lampiran 3) dalam bentuk pertanyaan. Untuk mengurangi bias dalam mengambil kesimpulan akhir, maka perlu dilakukan Food Recall 3 hari tidak berturut-turut sebagai data penunjang variabel kebiasaan makan. 
- Tingkat kebiasaan makan diperoleh dengan menggunakan kuesioner (lampiran 3) dalam bentuk pertanyaan.

- Cara pengumpulan data kadar Hemoglobin ( $\mathrm{Hb})$ diperoleh dengan melakukan pengambilan darah anak jalanan yang dilakukan dengan alat Digital Easy Touch $\mathrm{Hb}$ merek NESCO skala ukuran gram/dl.

Prosedur pemeriksaan dengan menggunakan alat ukur digital Easy Touch merk NESCO adalah (Anonim dalam Nugroho, 2010):

1. Ambil darah kapiler dengan lanset yang terdapat pada set peralatan

2. Letakkan darah pada monitor untuk mengetahui kadar haemoglobin (Hb)

3. Kemudian lihat pada layar monitor angka yang dihasilkan oleh alat pemeriksa kadar Haemoglobin $(\mathrm{Hb})$, kemudian di catat kedalam form pengisian pemeriksaan kadar Haemoglobin ( $\mathrm{Hb})$.

Pengolahan data dilakukan secara manual yang diperoleh dengan menggunakan kuesioner (lampiran 3) dalam bentuk pertanyaan kemudian di edit, lalu diberi kode, dan di entri dengan menggunakan komputer. Data tersebut meliputi :

Tingkat kebiasaan makanan yang diperoleh dengan menggunakan kuesioner (lampiran 3) dalam bentuk pertanyaan dimana setiap jawaban diberi skor dengan skor tertinggi 3 diikuti dengan skor 2 dan skor terendah 1 kemudian di golongkan berdasarkan interval, dengan cara sebagai berikut :

$$
\begin{aligned}
= & \frac{\text { Total Skor Tertinggi }- \text { Total Skor Terendah }}{\text { Kategori }} \\
= & \frac{45-15}{3} \\
=10 &
\end{aligned}
$$

Kemudian dikategorikan berdasarkan jumlah skor menjadi 3 tingkatan yaitu:

1. Total skor $35-45$ kategori baik

2. Total skor 25 - 34 kategori kurang

3. Total skor 15 - 24 kategori buruk

Tingkat gaya hidup yang diperoleh dengan menggunakan kuesioner (lampiran 3) dalam bentuk pertanyaan dimana setiap jawaban diberi skor dengan skor tertinggi 3 diikuti dengan skor 2 dan skor terendah 1 kemudian di golongkan berdasarkan interval dengan cara sebagai berikut :

$$
\begin{aligned}
&= \frac{\text { Total Skor Tertinggi }- \text { Total Skor Terendah }}{\text { Kategori }} \\
&= \frac{39-14}{3} \\
&=8,6 \approx 9
\end{aligned}
$$

Kemudian dikategorikan berdasarkan jumlah skor menjadi 3 tingkatan yaitu:

1. Total skor $31-39$ kategori baik

2. Total skor $22-30$ kategori cukup
3. Total skor $13-21$ kategori kurang

Pengolahan kadar hemoglobin $(\mathrm{Hb})$ di olah secara manual diperoleh dengan melakukan pengambilan darah anak jalanan kemudian penentuan kadar hemoglobin $(\mathrm{Hb})$ dilakukan dengan alat Digital Easy Touch $\mathrm{Hb}$ merek Nesco skala ukuran gram/dl. Selanjutnya dikategorikan menjadi 3 tingkatan yaitu (Supriasa, 2004):
1. Kadar $\mathrm{Hb}$ normal
$: 12-16 \mathrm{gr} / \mathrm{dl}$
2. Kadar $\mathrm{Hb}$ rendah
: $8.5-11,9 \mathrm{gr} / \mathrm{dl}$
3. Kadar $\mathrm{Hb}$ sangat rendah
: $5-8.4 \mathrm{gr} / \mathrm{dl}$

Data yang telah diolah dianalisis dengan menggunakan program SPSS versi 16.0 untuk melihat hubungan antara variabel menggunakan analisis univariat dan bivariat.

a. Analisis univariat untuk menggambarkan masingmasing variabel yang disajikan dalam distribusi frekuensi dan dianalisis berdasarkan presentase.

b. Analisis bivariat untuk melihat hubungan gaya hidup dengan kadar hemoglobin ( $\mathrm{Hb})$ serta melihat hubungan kebiasaan makan dengan kadar hemoglobin $(\mathrm{Hb})$ pada anak jalanan. Untuk melihat antar kedua variabel yang dimaksud dilakukan uji satistik dengan memakai metode uji Chi-Square. Dengan mengambil kesimpulan, jika $\mathrm{p}<0,05$ maka Ho ditolak yang berarti ada hubungan dan jika nilai $\mathrm{p}>0,05$ maka Ho diterima yang berarti antara kedua variabel tidak ada hubungan

\section{HASIL DAN PEMBAHASAN}

\section{A. Gambaran Umum Penelitian}

Anak jalanan adalah anak-anak yang masih berusia remaja dan menjelang dewasa, yang kesehariannya bekerja dijalanan untuk memenuhi kebutuhan hidupnya. Anak jalanan rentan terhadap perlakuan kekerasan dan tidak manusiawi dari orang disekelilingnya. Mereka tinggal dibawah kolong jembatan serta gedung-gedung yang tidak terpakai yang dekat dengan tempat mereka bekerja.

Biasanya anak jalanan melakukan aktifitas di tempat-tempat ramai yang menyebar di sekitar kota Medan seperti Simpang Lampu Merah Titi Kuning, Aksara, Juanda, Pringgan, serta Simpang Petisah dan sebagian mereka juga bekerja di sekitar terminal angkotan kota diantaranya Terminal Amplas dan Terminal Pinang Baris. Mereka biasanya bekerja secara berkelompok-kelompok, pekerjaan yang dilakukan diantaranya mengamen, berjualan, kuli angkut, penyemir sepatu dll.

\section{B. Karateristik Anak Jalanan \\ 1. Tempat Bekerja}

Faktor kemiskinan serta kekerasan rumah tangga, merupakan pemicu orang mencari alternatif pekerjaan di jalanan yang sangat keras. Kondisi ini menyebabkan banyak para remaja untuk memenuhi kebutuhan hidup menjadi pengamen. Pekerjaan pengamen bukan hanya sekedar tetapi menjadi mata pencaharian terutama pada 
anak yang tidak mempunyai tempat tinggal yang tetap. Tempat anak jalanan bekerja biasanya dipusat keramaian dan Simpang lampu merah. Distribusi anak jalanan berdasarkan tempat bekerja dapat dilihat pada tabel 1 berikut ini :

Tabel 1. Distribusi Anak Jalanan Berdasarkan Tempat Bekerja Tahun 2013

\begin{tabular}{lcc}
\hline $\begin{array}{r}\text { Tempat } \\
\text { Bekerja }\end{array}$ & n & \% \\
\hline Aksara & 15 & 20.83 \\
Juanda & 9 & 12.50 \\
Pinang Baris & 7 & 9.72 \\
Pringgan & 10 & 13.89 \\
Simpang & 8 & \\
Petisah & & 11.11 \\
Terminal & 20 & \\
Amplas & 3 & 27.77 \\
Titi Kuning & 72 & 4.17 \\
$\quad$ Total & 700.00 \\
\hline
\end{tabular}

Berdasarkan tabel 1 dapat diketahui bahwa tempat bekerja anak jalanan menyebar dibeberapa tempat keramaian kota Medan, diantaranya berada di Terminal Amplas yaitu sebanyak 20 orang $(27,77 \%)$ dimana di Terminal Amplas adalah tempat berkumpulnya angkot maupun bus dan mereka disana dapat melakukan pekerjaan sampingan selain mengamen misalnya mengangkat barang, menyapu-nyapu angkot, berjualan, dsb. Kemudian ditemukan sebanyak 15 orang $(20,83 \%)$ anak jalanan bekerja disekitar Lampu Merah Aksara, dengan adanya 4 mall besar di Aksara menyebabkan mereka sering berkumpul di setiap depan mall, sehingga lebih memungkinkan mereka lebih mudah memperoleh uang. Dengan cara berjualan atau membuat tato, bahkan menjadi kuli angkut barang disamping sebagai pengamen yang memang pekerjaan utama anak jalanan yang berada di Aksara.

\section{Umur}

Umur adalah rentang kehidupan yang diukur dengan tahun. Distribusi anak jalanan berdasarkan kelompok umur (tahun) dapat dilihat pada tabel 2 berikut ini :

Tabel 2. Distribusi Anak Jalanan Berdasarkan Kelompok Umur Tahun 2013

\begin{tabular}{ccc}
\hline $\begin{array}{c}\text { Kelompok Umur } \\
\text { (tahun) }\end{array}$ & n & \% \\
$10-14$ & 4 & 5.56 \\
$15-19$ & 41 & 56.94 \\
$20-24$ & 27 & 37.50 \\
Total & 72 & 100.00 \\
\hline
\end{tabular}

Berdasarkan hasil penelitian yang diperoleh dari lokasi penelitian bahwa umur anak jalanan dalam penelitian ini bervariasi dari terendah umur 14 tahun sampai tertinggi umur 24 tahun dengan rata-rata umur
18,60 tahun. Menggunakan pengelompokan umur menurut Departemen Kesehatan, maka kelompok umur terbanyak adalah 15-19 tahun sejumlah 56,94\% dimana faktor-faktor yang mempengaruhi anak berada dalam kehidupan jalanan adalah kesulitan keuangan atau tekanan kemiskinan, ketidak harmonisan keluarga, serta pengaruh teman dan lingkungan. Kemungkinan lainnya adalah pada usia 15-19 tahun mereka mengalami pubertas sehingga dari kejiwaan masih labil dan gampang terpengaruh. Pada usia puberitas remaja ini biasanya adalah usia mencari jati diri sehingga mereka lebih memilih untuk bekerja dan hidup dijalanan (Handayani, 2009).

\section{Jenis Kelamin}

Berdasarkan gambar 1 dapat diketahui bahwa karateristik anak jalanan berdasarkan jenis kelamin laki-laki sebanyak 46 orang (64\%), dan perempuan sebanyak 26 orang (36\%). Hal ini karena anak jalanan berjenis kelamin laki-laki lebih berani serta tidak terlalu banyak mengandung resiko bila hidup dan bekerja di jalanan seperti mengamen, berjualan, menyemir, peminta-minta, kuli serta pemulung di setiap Simpang Lampu Merah maupun Terminal. Sedangkan anak jalanan perempuan lebih rawan mengalami kekerasan fisik, pelecehan seksual, serta eksploitasi seksual bahkan banyak juga yang merasa risih dan malu menjadi anak jalanan (Pramuchtia, 2010). Distribusi anak jalanan berdasarkan jenis kelamin dapat dilihat pada gambar 1 berikut ini :

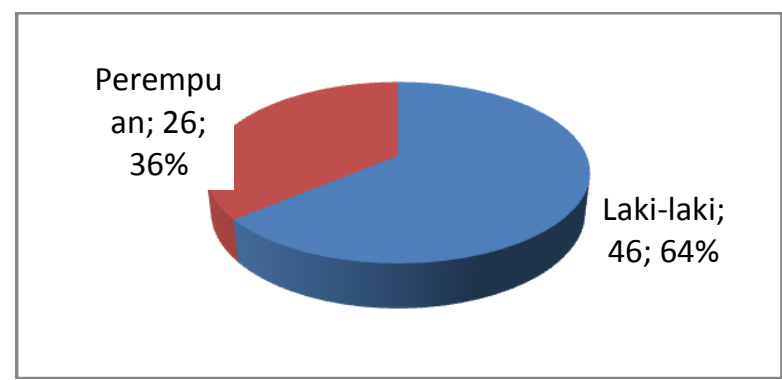

Gambar 1. Distribusi Anak Jalanan Berdasarkan Jenis Kelamin Tahun 2013

\section{Jenis Pekerjaan}

Pola kerja ank jalanan merupakan bagian dari strategi bertahan hidup yaitu untuk memperoleh uang (Nur'aini, 2010). Sesuai dengan batasan operasional bahwa sampel penelitian adalah anak jalanan yang melakukan minimal 2 jenis pekerjaan, maka ditemukan $51,39 \%$ anak jalanan yang melakukan lebih dari 2 jenis pekerjaan setiap harinya. Distribusi anak jalanan berdasarkan jenis pekerjaan dapat dilihat pada tabel 3 berikut ini :

Tabel 3 Distribusi Anak Jalanan Berdasarkan Jenis Pekerjaan Tahun 2013

\begin{tabular}{ccc}
\hline Pekerjaan & n & \% \\
\hline 2 Jenis Pekerjaan & 35 & 48.61 \\
>2 Jenis Pekerjaan & 37 & 51.39 \\
Total & 72 & 100.0 \\
\hline
\end{tabular}


Pekerjaan-pekerjaan yang mereka lakukan pada tabel 3 rutin dilakukan hampir setiap hari pada lokasi yang sama. Pekerjaan utama paling banyak dilakukan anak jalanan adalah mengamen yaitu sebanyak 53 orang $(73,6 \%)$ karena jenis pekerjaan mengamen diduga lebih cepat menghasilkan uang hasil ini sejalan dengan penelitian Nur'aini tahun 2010. Mereka juga memiliki pekerjaan sampingan seperti berjualan yaitu sebanyak, peminta minta, tukang semir, menyapu angkot, tukang lap,kuli dan pemulung. Biasanya mereka melakukan aktifitas antara 418 jam per hari, tetapi jika melakukan satu atau lebih pekerjaan rata-rata 11 jam kerja per hari. Sedangkan waktu istirahat dilakukan sembari makan yang tidak mereka tentukan waktunya karena kegiatan makan ini dilakukan apabila mereka telah memperoleh uang.

\section{Gaya Hidup}

Kerasnya hidup dijalanan menyebabkan gaya hidup anak jalanan kelihatan lebih buruk dibandingkan orang biasa. Gaya hidup anak jalanan semakin lebih buruk karena mereka merokok, mengkonsumsi narkoba (lem) dan jarang mandi. Gaya hidup seperti ini rentan terhadap masalah kesehatan terutama masalah gizi. Distribusi anak jalanan berdasarkan gaya hidup dapat dilihat pada gambar 2 berikut ini :

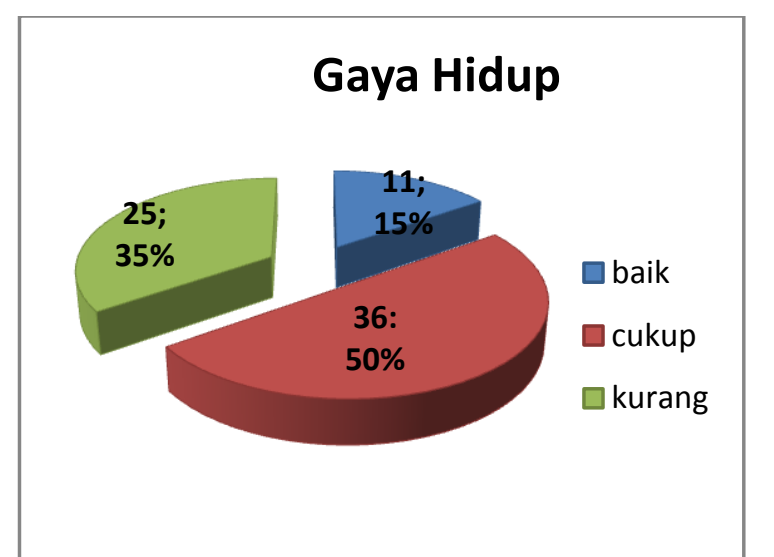

\section{Gambar 2 Distribusi Anak Jalanan Berdasarkan Gaya Hidup Tahun 2013}

Dari gambar 2 menunjukkan bahwa kategori gaya hidup anak jalanan dengan kategori cukup sebesar 36 orang (50\%), anak jalanan dengan gaya hidup kurang sebanyak 25 orang (35\%). Hanya sebanyak 11 orang $(15 \%)$ yang mempunyai gaya hidup baik.

Anak jalanan yang mempunyai gaya hidup baik adalah anak-anak jalanan yang masih duduk di bangku kuliah dan sekolah, sehingga mereka masih dituntut untuk hidup teratur serta membersihkan tubuh minimal 1 kali sehari. Anak jalanan yang masih sekolah dan kuliah ini juga, tidak merokok dan mengkonsmsi alkohol. Sedangkan anak jalanan yang mempunyai gaya hidup cukup dan kurang merupakan anak jalanan yang sering mengkonsumsi narkoba/lem, alkohol, merokok dan higiene sanitasi kurang. Rendahnya higiene sanitasi personal pada anak jalanan akibat tidur di jalan dan bekerja dilingkungan tidak sehat merupakan alasan mengapa anak jalanan mudah terkena penyakit (UNICEF dalam Nur'aini, 2010).

Usaha yang dapat dilakukan untuk mencegah datangnya penyakit pada higiene sanitasi diantaranya, mandi minimal dua kali sehari sementara pada hasil penelitian terdapat lebih banyak anak jalanan mandi 1 kali sehari yaitu sebanyak 45 orang $(62.5 \%)$ dan bahkan ada anak jalanan sebanyak 23 orang (31.9\%) yang tidak pernah mandi dalam 1 hari. Higiene sanitasi yang kedua yaitu menyikat gigi dimana dari hasil penelitian diperoleh anak jalanan yang tidak membiasakan menggosok gigi sebanyak 33 orang $(45,8 \%)$, demikian juga dengan mencuci tangan sebelum makan dari hasil penelitian diperoleh sebanyak 49 orang $(68.1 \%)$ anak jalanan yang kadang-kadang mencuci tangan sebelum makan. Higiene sanitasi yang baik dapat membantu dalam pencegahan penyakit seperti diare, kecacingan, dll (Handayani, 2009).

\section{Kebiasaan makan}

Kebiasaan makan anak jalanan adalah frekuensi dan jenis makanan yang dikonsumsi anak jalanan serta bagaimana cara memperolehnya (Nur'aini, 2010). Kebiasaan makan biasanya menyangkut jumlah, jenis, waktu, serta berapa kali mereka makan dalam 1 hari. Kebiasaan makan anak jalanan juga menyangkut tentang bagaimana mereka memperoleh uang untuk biaya makan. Distribusi anak jalanan berdasarkan kebiasaan makanan dapat dilihat pada gambar 3 berikut ini :

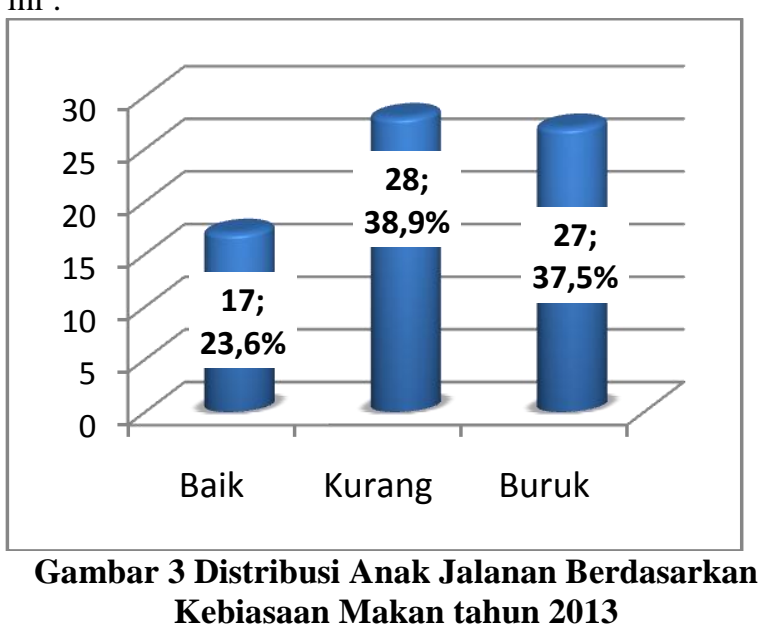

Dari gambar 3 menunjukkan bahwa kebiasaan makan anak jalanan dengan kategori kurang sebesar 28 orang $(38,9 \%)$, anak jalanan dengan kebiasaan makan buruk sebanyak 27 orang (37,5\%). Hanya sebanyak 17 orang $(23,6 \%)$ yang mempunyai kebiasaan makan baik.

Anak jalananan yang masih mempunyai kebiasaan makan baik disebabkan karena mereka adalah anak jalanan yang masih pulang ke rumah masing-masing pada waktu-waktu tertentu, sehingga dengan demikian kebiasaan makannya masih mengikuti pola makan keluarga yang teratur. Hal ini dapat dilihat pada identitas kepulangan kerumah yang mengatakan ada sebanyak 20 orang $(27,8 \%)$ anak jalanan yang masih pulang kerumah dan ada sebanyak 13 orang $(18,1 \%)$ 
anak jalanan yang jarang pulanh kerumah. Sedangkan kebiasaan makan anak jalanan dengan kategori kurang dan buruk merupakan kebiasaan makanan yang tidak teratur serta jumlah yang dikonsumsi juga kurang. Dari hasil penelitian diperoleh anak jalanan yang tidak membiasakan sarapan pagi sebanyak 35 orang $(48.6 \%)$, anak jalanan yang tidak membiasakan makan sesuai waktunya sebanyak 39 orang (54.2\%), sementara setelah selesai makan anak jalanan mengkonsumsi alkohol sebanyak 35 orang (48.6\%).

Konsumsi makanan juga dipengaruhi oleh pendapatan ketika mereka memperoleh uang mereka lebih mendahulukan membeli minuman yang mengandung energi seperti alkohol, kikubima, extrajoss. Sementara pendapatan yang diperoleh anak jalanan menentukan jenis, kualitas dan jumlah pangan yang dikonsumsi. Konsumsi makanan secara langsung mempengaruhi kesehatan anak jalanan (Handayani, 2009).

\section{E. Kadar Hemoglobin (Hb)}

Pada anak jalanan salah satu parameter yang dapat diukur untuk melihat anemia atau tidaknya yaitu kadar Hemoglobin $(\mathrm{Hb})$. Hemoglobin $(\mathrm{Hb})$ adalah protein yang kaya akan zat besi. Hemoglobin ( $\mathrm{Hb}$ ) merupakan senyawa pembawa oksigen pada sel darah merah. Penurunan kadar Hemoglobin $(\mathrm{Hb})$ dari normal berarti sedang mengalami kekurangan darah yang disebut anemia. Anemia hampir dialami oleh semua tingkatan umur dan salah satunya adalah remaja dan dewasa (Almatsier, 2004). Distribusi anak jalanan berdasarkan kadar Hemoglobin $(\mathrm{Hb})$ dapat dilihat pada gambar 4 berikut ini :

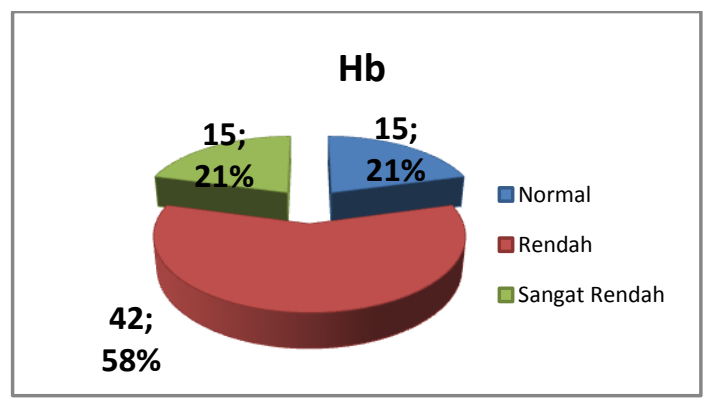

Gambar 4 Distribusi Anak Jalanan Berdasarkan Kadar Hemoglobin (Hb) tahun 2013

Dari gambar 4 menunjukkan bahwa sebagian besar anak jalanan mempunyai kadar hemoglobin $(\mathrm{Hb})$ di bawah ambang normal berkisar antara 12-16 gr/dl yaitu sebesar 42 orang (58\%) anak jalanan yang mempunyai kadar hemoglobin $(\mathrm{Hb})$ rendah, dan bahkan sebanyak 15 orang $(21 \%)$ anak jalanan mempunyai kadar hemoglobin $(\mathrm{Hb})$ sangat rendah.

Anak jalanan yang memiliki kadar hemoglobin (Hb) normal dimungkinkan karena anak jalanan tersebut masih baru bekerja dijalanan dan selalu pulang ke rumah orang tuanya. Sedangkan anak jalanan yang mempunyai kadar haemoglobin rendah dan sangat rendah diakibatkan oleh konsumsi makanan yang kurang baik terutama jenis makanan yang mengandung zat besi, protein, B12, dan Vitamin C, aktifitas yang berlebihan ( tidak seimbang dengan masukan/ intake makanan) dan juga disebabkan oleh adanya penyakit infeksi seperti diare, kecacingan, dll (Sinaga, 2005). Dari hasil penelitian diperoleh sebanyak 50 orang (69.4\%) anak jalanan makan 2 kali sehari dan bahkan ada sebanyak 18 orang $(25 \%)$ anak jalanan makan 1 kali sehari. Demikian juga dengan jam tidur dapat mempengaruhi tingkat kadar hemoglobin (Hb) seseorang, dari hasil penelitian diperoleh sebanyak 48 orang $(66.7 \%)$ anak jalanan dengan lama tidur dibawah $<4$ jam, dan sebanyak 22 orang $(30.6 \%)$ anak jalanan dengan lama tidur 4-6 jam.

\section{F. Hubungan Gaya Hidup, Kebiasaan Makan Dengan Kadar Hemoglobin (Hb) \\ 1. Hubungan Gaya Hidup Dengan Kadar Hemoglobin (Hb)}

Gaya hidup menggambarkan keseluruhan diri seseorang dalam berinteraksi dengan lingkungannya. Gaya hidup yang baik seperti tidak merokok, mengkonsumsi narkoba/lem, dan minum alkohol. Gaya hidup yang baik juga dapat dinilai dari hygiene sanitasi personal yaitu seperti mandi 2 kali sehari, menggosok gigi, mencuci tangan, menggunting kuku, menggunakan pakaian bersih. Hygiene personal yang baik dapat membantu dalam pencegahan penyakit infeksi seperti diare, kecacingan, dll (Widyati dalam Nur'aini, 2010).

Tabel 5 Distribusi Anak Jalanan Berdasarkan Hubungan Gaya Hidup Dengan Kadar Hemoglobin (Hb) Tahun 2013

\begin{tabular}{|l|c|c|c|c|c|c|}
\hline \multirow{3}{*}{ Gaya } & \multicolumn{4}{|c|}{ Kadar Hemoglobin Darah } \\
\cline { 2 - 7 } & \multicolumn{2}{|c|}{ Normal } & \multicolumn{2}{c|}{ Rendah } & \multicolumn{2}{c|}{$\begin{array}{c}\text { Sangat } \\
\text { Rendah }\end{array}$} \\
\cline { 2 - 7 } & $\mathrm{n}$ & $\%$ & $\mathrm{n}$ & $\%$ & $\mathrm{n}$ & $\%$ \\
\hline Baik & 9 & 12.5 & 2 & 2.77 & 0 & 0 \\
\hline Cukup & 3 & 4.16 & 31 & 43.05 & 2 & 2.77 \\
\hline Kurang & 3 & 4.16 & 9 & 12.5 & 13 & 18.05 \\
\hline
\end{tabular}

Dari tabel 5 menunjukkan bahwa semakin baik gaya hidup anak jalanan maka semakin baik kadar hemoglobin $(\mathrm{Hb})$, begitu juga sebaliknya jika semakin kurang gaya hidup anak jalanan maka semakin rendah kadar hemoglobin $(\mathrm{Hb})$.

Dari hasil uji statistic menggunakan uji ChiSquare di peroleh nilai $\mathrm{p}=0.000<0.05$ artinya ada hubungan yang bermakna antara gaya hidup dengan kadar Hemoglobin (Hb).

Bahwa gaya hidup yang sembarangan seperti tidak mandi yaitu terdapat anak jalanan tidak pernah mandi sebanyak 23 orang (311.9\%), 1 kali mandi sebanyak 45 orang $(62,5 \%)$, anak jalanan dengan perokok berat yaitu sebanyak 22 orang (30.6\%), perokok sedang sebanyak 47 orang $(65,3 \%)$, anak jalanan yang tidak membiasakan gosok gigi sebanyak 33 orang (45.8\%), kadang-kadang sebanyak 33 orang $(45.8 \%)$, anak jalanan yang tidur $<4$ jam sebanyak 48 orang (66.7\%), tidur 4-6 jam sebanyak 22 orang (30.6\%). Dengan gaya hidup seperti itu anak jalanan rentan terkena penyakit. Bila anak jalanan sakit maka 
makanan yang dikonsumsi akan menjadi lebih sedikit untuk pembentukan hemoglobin $(\mathrm{Hb})$. Anak jalanan rentan terhadap penyakit infeksi seperti TBC, cacingan yang dapat menyebabkan Anemia. Hal ini sesuai dengan pernyataan Handayani, 2009 yang menyatakan bahwa anak jalanan yang tinggal dan menetap di bawah kolong jembatan dan ruko-ruko yang tidak terpakai, biasanya mempunyai gaya hidup yang buruk yaitu jarang mandi serta pada saat berkumpul biasanya mereka merokok sambil mengkonsumsi alkohol.

\section{Hubungan Kebiasaan Makan Dengan Kadar Hemoglobin (Hb)}

Kebiasaan makan dinilai dari frekuensi makan (minimal nasi, lauk pauk dan sayur), komposisi makanan seimbang dan makanan pantangan. Kebiasaan makan yang baik juga dinilai dari makan yang bervariasi, waktu makan, pola makan yang teratur. Sementara kebiasaan makan yang tidak teratur dapat mengganggu kesehatan dalam melakukan aktivitas.

\begin{tabular}{|c|c|c|c|c|c|c|}
\hline \multirow{3}{*}{$\begin{array}{c}\text { Kebiasaan } \\
\text { Makan }\end{array}$} & \multicolumn{2}{|c|}{ Kadar Hemoglobin Darah } & & & & \\
\hline & \multicolumn{2}{|c|}{ Normal } & \multicolumn{2}{|c|}{ Rendah } & \multicolumn{2}{|c|}{$\begin{array}{r}\text { Sangat } \\
\text { Rendah }\end{array}$} \\
\hline & $\mathrm{N}$ & $\%$ & $\mathrm{n}$ & $\%$ & $\mathrm{n}$ & $\%$ \\
\hline Baik & 7 & 9.72 & 9 & 12.50 & 1 & 1.39 \\
\hline Kurang & 5 & 6.94 & 15 & 20.83 & 8 & 11.1 \\
\hline Buruk & 3 & 4.17 & 18 & 25.0 & 6 & 8.33 \\
\hline
\end{tabular}

Dari tabel 4 menunjukkan bahwa kebiasaan makan anak jalanan dengan kategori baik, kurang bahkan sangat kurang mempunyai kadar hemoglobin $(\mathrm{Hb})$ rendah.

Dari hasil uji statistic menggunakan uji ChiSquare di peroleh nilai $\mathrm{p}=0.096>0.05$ artinya tidak ada hubungan yang bermakna antara kebiasaan makan dengan kadar Hemoglobin ( $\mathrm{Hb})$. Hal disebabkan oleh karena pembentukan hemoglobin ( $\mathrm{Hb})$ itu membutuhkan waktu yang lama sekitar 120 hari dibandingkan dengan pembentukan Kadar Glukosa Darah (KGD) yang berasal dari KH. Selain itu, anak jalanan juga ternyata mempunyai kebiasaan makan mengkonsumsi alkohol yaitu sebanyak 35 (50\%) orang. Sedangkan, anak jalanan yang menggunaan obat-obatan/lem sebanyak $33(45 \%)$ orang. Untuk bertahan lama dalam beraktifitas dijalan anak jalanan juga mengkonsumsi minuman berenergi (kukubima, extrajoss) yaitu sebanyak 37 orang (51\%).

Menurut penelitian Tya, 2010 alkohol dapat menghambat penyerapan Fe. Juga akibat kebiasaan makan yang tidak teratur dapat menyebabkan gangguan pencernaan, dan ini juga dapat menyebabkan gangguan penyerapan zat-zat gizi seperti protein, vitamin $\mathrm{C}$ yang membantu proses pembentukan Hemoglobin ( $\mathrm{Hb})$.

\section{KESIMPULAN DAN SARAN}

A. Kesimpulan

1. Gaya Hidup anak jalanan di Medan lebih banyak kategori kurang yaitu sebesar 36 orang (50\%).

2. Kebiasaan Makan anak jalanan di Medan lebih banyak kategori sedang yaitu sebesar 28 orang $(38,9 \%)$.

3. Kadar Haemoglobin (Hb) anak jalanan di Medan lebih banyak kategori rendah yaitu sebesar 42 orang $(58 \%)$

4. Ada hubungan yang signifikan $(\mathrm{p}=0.000<0.05)$ antara gaya hidup dengan kadar haemoglobin (Hb).

5. Tidak ada hubungan yang signifikan ( $\mathrm{p}=0,096>$ 0.05 ) antara kebiasaan makan dengan kadar haemoglobin $(\mathrm{Hb})$.

B. Saran

1. Perlu dilakukan kerjasama antara para stakeholder seperti Pemerintah Kota setempat, LSM serta Pemerhati anak jalanan untuk upaya memberikan strategi-strategi preventif, kreatif, dan berdaya guna untuk mempertahankan hidupnya.

2. Perlu adanya advokasi yang aktif, kolaboratif, dan terus menerus untuk membantu meningkatkan kehidupan anak jalanan agar tidak mengalami kekerasan fisik serta pelecehan seksual.

3. Perlu adanya jasa - jasa untuk bantuan kesehatan dan pendidikan bagi anak jalanan, untuk mempertahankan hidupnya dengan cara mendirikan lebih banyak rumah singgah untuk anak terlantar yang hidup dijalanan.

4. Bagi pemerhati anak jalanan disarankan sebaiknya dilakukan penyuluhan rutin setiap bulan agar anak jalanan dapat terpapar tentang pola hidup sehat, hygienitas makanan serta pentingnya teratur makan bagi anak jalanan.

\section{DAFTAR PUSTAKA}

Almatsier, Sunita. 2004. Prinsip Dasar Ilmu Gizi. Gramedia Pustaka Utama, Jakarta.

Aritonang, EY. 2010. Anemia Gizi Besi. Universitas Pembangunan Veteran.

Djariyanto. 2008. Hubungan Antara Lama Menstruasi dan Kadar Hemoglobin pada Remaja Putri SMA Negri 2 Sukoharjo. Program Studi Kesehatam Masyarakat Fakultas Ilmu Kesehatan Universitas Muhammadiyah Surakarta.

Handayani, Kartika. 2009. Identifikasi Anak Jalanan di Kota Medan. Skripsi. Fakultas Kedokteran Universitas Sumatera Utara, Medan.

Hidayah, Ainun. 2011. Kesalahan-Kesalahan Pola Makan Pemicu Seabrek Penyakit Mematikan. Buku Biru, Yogyakarta

Husni, M Thamrin, dkk. 2008. Kebiasaan Makan dan Pengetahuan Reproduksi. Departemen Gizi Masyarakat IPB 
Jalaluddin, 2009. Pengaruh Sanitasi Lingkungan, Personal Hygiene Dan Karateristik Anak Terhadap Infeksi Kecacingan. Tesis. Sekolah Pasca Sarjana Universitas Sumatera Utara. Medan

Khomsan, A. 2004. Teknik Pengukuran Gizi. Jurusan Gizi Masyarakat Dan Sumberdaya Keluarga, Fakultas Pertanian Institu Pertanian Bogor. Bogor.

Kusmiran, E. 2011. Kesehatan Reproduksi Remaja dan Wanita. Salemba Medika, Jakarta.

Oktaria, Yudit Kristiani Pardede. 2008. Konsep Diri Anak Jalanan Usia Remaja. Fakultas Psikologi Universitas Gunadarma.

Pamuchtia, Yunda, Nurmala K. Pandjaitan. Konsep Diri Anak Jalanan. Kasus Anak Jalanan di Kota Bogor Provinsi Jawa Barat.

Notoatmodjo, Soekidjo. 2010. Metodologi Penelitian Kesehatan. Rineka Cipta, Jakarta.

Nur'aini, 2010. Pola Aktivitas, Konsumsi Pangan, Status Gizi dan Kesehatan Anak Jalanan di Kota Bandung.

Sari, Halinda Lubis, Evawany Aritonang. 2008. Analisis Kadar Hemoglobin Darah pada Buruh Wanita di Perusahaan Makanan Beku (Cold Storage) Pt X Belawan. Fakultas Kesehatan Masyarakat USU.

Siagian, Albiner. 2010. Epidemiologi Gizi. Erlangga Medikal Seris, Jakarta.

Sinaga, E. 2005. Hubungan Antara Kadar Hb dengan Prestasi Belajar. Mutiara Kesehatan Indonesia.
Siregar, Hairani. 2004. Faktor Dominan Anak Menjadi Anak Jalanan di Kota Medan. Tesis. Program Magister Studi Pembangunan Program Pasca Sarjana Universitas Sumatera Utara Medan.

Supriasa, I Dewa Nyoman, dkk. 2002. Penilaian Status Gizi. Buku Kedokteran, Jakarta.

Suyanto, B. 2010. Masalah Sosial Anak. Kencana, Jakarta.

Tarigan, Novriani, dkk. 2011. Pedoman Penulisan Karya Tulis Ilmiah. Kementrian Kesehatan Republuk Indonesia Politeknik Kesehatan Medan.

Tya, Eka Yulianti, 10 Mei 2010. Kadar Alkohol Dalam Darah, Detik Bandung, http://bandung.detik.com/read/2010/05/10/161939 /1354615/486/kadar-alkohol-dalam-darah-05persen-siap-siap-cuci-darah, diakes tanggal 6 agustus 2010.

Widianti, E. 2007. Remaja Dan Permasalahannya : Bahaya Merokok, Pemyimpangan Seks pada Remaja, dan Bahaya Penyalaahgunaan Minuman Keras/ Narkoba. Universitas Padjadjaran Fakultas Ilmu Keperawatan Jatinagor.

Yamani, Nuari. 2009. Dampak Perilaku Penggunaan Minuman Keras Dikalangan Remaja. Fakultas Psikologi Universitas Muhammadiyah Surakata. 